\title{
The role of the Holy Spirit in Ghanaian \\ Pentecostal churches: A missiological study
}

NGTT DEEL 55, NO 1, 2014

\section{White, Peter and Niemandt, Cornelius JP}

Science of Religion and Missiology

University of Pretoria

\begin{abstract}
This article discussed the role of the Holy Spirit in Ghanaian Pentecostal churches from a missiological perspective. In order to achieve the aim for the topic, the article focused on one of the major factors that led to the rise and popularity of Pentecostalism in Ghana; i.e. the concern of the indigenes about their worldview not being addressed by the Western missionaries which came to serve in Ghana. The article argued that, in the desire for Ghanaians to have their worldview addressed, they resorted to Pentecostalism - a movement first introduced into Ghana by the African Initiated Churches. It is also argued that, though one of the factors that have made Pentecostalism to be accepted by Ghanaians is how it has addressed their worldview; Ghanaian Pentecostal Churches are of the view that the role of the Holy Spirit is the major factor for this increase.
\end{abstract}




\section{INTRODUCTION}

The arrival of the European missionaries in the 15th century to the then Gold Coast State of West Africa (i.e. Ghana) brought Christianity to the land, and made an unforgettable imprint on Ghanaian soil (Darkwa 2013). According to census figures from the year 2010, out of Ghana's 18.9 million people, Christians made up $71.2 \%$ (percent) of the population. Pentecostals form the bulk of the Christian population in the country (Ghana Statistical Service 2012:1, 6, 40). Larbi (2002:99) argues that, presently in Ghana, the growing edges of Christianity in its most vital and dynamic forms are found in the Pentecostal-Charismatic churches. In spite of the diversity ${ }^{1}$ in the Pentecostal movement (i.e. churches), they are at least - from a demographical point of view - the most important religious trend in Ghana (Larbi 2001:xii). For the purpose of this research, Ghanaian Pentecostals are referred to as a group of Christians who emphasize salvation in Christ as the basis for one to be filled with the Holy Spirit, and in which the 'Spirit phenomenon' (including speaking in tongues, prophecies, visions, healing and miracles in general) is perceived as in line with what happened in the early church in the Acts of the Apostles and accepted as a continuous experience in the contemporary church as a sign of the presence of God and experience of His Spirit (Asamoah-Gyadu 2005:12). According to Asamoah-Gyadu (2013:10-11), what defines Pentecostalism is the experience of the Holy Spirit in transformation, radical discipleship and manifestations of the acts of power that demonstrate the presence of the kingdom of God among His people. The Holy Spirit is therefore the power of the transition, mediation, communication and history which takes place first in the life of God Himself, and then consequently in our life and our relationship with Christ Jesus (Flett 2010:239). Since Pentecostalism flows from the ministry of the Holy Spirit, this paper therefore seeks to answer the following questions:

- "What provoked the Holy Spirit Movement (Pentecostalism) to manifest in the church history of Ghana in the face of Ghanaians worldview and culture?"

- "How do Ghanaian Pentecostals understand the role of the Holy Spirit in Ghanaian Pentecostal churches?"

1 In Ghana, we have the Classical Pentecostal Churches and the Neo Pentecostal Churches. The classical Pentecostals are the four main line Pentecostals Churches, namely: Christ Apostolic Church International; The Apostolic Church, Ghana; The Church of Pentecost; and Assemblies of God. The Neo Pentecostals are the Charismatic churches and Independent Pentecostal Churches popularly known as "one man churches". However, they are all members of the Ghana Pentecostal and Charismatic Council. 


\section{WESTERN MISSIONARIES AND THE TRADITIONAL WORLDVIEW OF GHANAIANS}

Pentecostalism, as we see it today in Ghana, did not come into being in a vacuum - certain factors led to impact and role of Pentecostalism in Ghanaian Church history. Although Western missionaries initially came to plant Christianity in Ghana, Ghanaian Christians were experiencing a missing link. That is, they saw that their spiritual needs were not being met by the then mainline churches planted by the Western missionaries (e.g. missionaries from the Roman Catholic Church, the Anglican Church, the Presbyterian Church of Ghana, and the Methodist Church [Busia 1972:239-246]). In Williamson's (1965:152-175) comparative study of the impact of Akan Religion and the Christian Faith, he concluded that the Western missionaries did very well in meeting the needs of Ghanaians at the social and economic level, but failed to make any significant and lasting impact on the religious level - mainly because they did not address the traditional worldview of Ghanaians, a worldview embedded in the belief in spirits.

In this section we briefly discuss the African traditional worldview in general, and the Ghanaian worldview in particular. The analysis of the African traditional worldview will cast more light on how the understanding of the working of the Holy Spirit in Ghanaian people could take root so rapidly and easily. Western missionaries, especially those from mainline churches, seem to have been less at ease making connections to the Ghanaian traditional religion than missionaries from the Pentecostal Movement.

According to Rusbult (2013), a worldview is a mental model of reality, a framework of ideas and attitudes about the world, ourselves and life. It is a comprehensive system of beliefs of people, communities and nations. People's worldview is affected by factors such as their inherited characteristics, background, experiences, life situations, their values, attitudes, the habits they have developed, and more. Kraft (1996:52) defines worldview as culturally structured assumptions, values, and commitments or allegiances underlying people's perceptions of reality and their responses to those perceptions. In his view, worldview is not separate from culture. It is included in culture as the structuring of the deepest level of presuppositions on the basis of which people live their lives.

The Ghanaian traditional worldview, which is also found in many other parts of Africa, about spirits displays the following characteristics: In African traditional religion there is no division and/or differentiation between the animate and inanimate, the spirit and matter, the living and non-living, the dead and living, the physical and metaphysical, the secular and sacred, the body and the spirit, etc. Generally, in the 
traditional African's view, they believe that everything (human beings included) is in constant relationship with one another and with the invisible world, and that people are in a state of complete dependence upon those invisible powers and beings (Cilliers 2013:10). The Ashanti or the Akans of Ghana, who are found in the Southern part of the country, believe that these divinities make their abode in trees, rivers, rocks, mountains, and in the sky. Their chiefs keep a three-forked branch of tree, used as an altar, in their compounds. This tree is known as "nyame dua" which means, "God's tree". If they want to offer any sacrifice to "God", that is where it is done (Mbiti 2012:199-200). In fact, this is not only practiced among the Akans of Ghana, but also the Ewes of the Volta Region. One of the researchers remembers that, in his childhood visits to his village in the Volta Region of Ghana, "there was always a pot on a three-forked tree - 'nyame dua' - in our compound, and in the pot there was always water which the entire family would have to use to wash their face. And it is believed that the 'soul' of the family is linked to the three-forked 'nyame dua' and therefore must be preserved for generations to come" (Mbiti 2013:205, 215). Generally, both the Akan and the Ewes believe that their many divinities "abosom" or "mawu Sowlui" - are "God's servants" and/or "mouthpieces", acting as go-between between him and his creatures. They also believe that these deities or spirits act as guardians of families and individuals.

Inferring from what has been said so far; it could be concluded that, before the arrival of the Western missionaries to the Gold Coast, the indigenes were on the whole practicing African traditional religions. According to Sarpong (2012:95-97), the then indigenes had already believed in a Supreme Being - "Onyakopong" - which means a God who supersedes other gods (or in other words the Almighty God). His argument states that, in spite of their view about "Onyakopong", they also believe in other deities, spirits and ancestral spirits - with the view that they are all intertwined and are in constant relationship with all living beings. These deities demand worship and are said to possess supernatural powers, with which they punish or reward their worshippers. In addition to Sarpong's view, Mbiti (2012:6, 9-15) argues that Africans believe that there is only one Supreme God; however, this view about God is influenced by factors such as geographical location, culture, language, social, and political factors. He further states that the indigenous names of God are always present in the worldviews of African people, and have been passed down through the generations through oral tradition. In his conclusion, he emphasizes that "there is, therefore, no place for atheism or denial of God's existence in traditional African communities" (Mbiti 2012:6, 9-15), for "Africans are ontologically attached to God" (Mbiti 2012:6, 9-15). 
In contrast to this, the Western Missionaries encountered Ghanaian traditional worldview and religion from a background of Christianity embedded in the "Enlightenment" (Kalu 2005:228). That is to say, they came with the perception and approach that presented them as superiors and viewed Ghanaian traditional worldview and culture as paganism, which made their missions almost a non-starter. Williamson (1965:159-164) attests to this fact in his comparative study of Christianity and Akan Religion. He argues that the Western Missions-related churches, by and large, are still an alien institution; with the reason being that it failed to root itself in the life and institutions of the Akan people - the Christian church, denominationally implanted from the West, has substantially retained its original forms and expressed itself in Western modes. Kingsley (Warren 1967:15 cites Kingsley) observed that most of the early missionaries regarded the Africans' minds as jugs, which had only to be emptied of the stuff which was in them and refilled with the particular form of doctrine that the missionaries were teaching. This, therefore, caused the Western missionaries to undermine indigenous Ghanaians, their worldview and their culture; which in turn led to the local people referring/approaching Christianity as the "white man's religion". Asamoah-Gyadu (2013:12) points out that one of the major setbacks of the missionary approach of the mainline churches was the way they marginalized and underemphasized the African pneumatic phenomena.

In addition to Asamoah-Gyadu's view, Brenno (2013:7-8) states that the Western missionaries overlooked the role of the African worldview in their approach to presenting the gospel to Africans. They saw the African traditional worldview on spirituality as merely superstition, and thus did not help to find adequate alternative solutions. The consequence of this approach was that young Christians lived a double-life, i.e. had a "double allegiance", which was in effect understood by the missionaries as hypocrisy. Having said this, one cannot totally blame the missionaries for their approach to the African culture and worldview - in agreement with Walls (1996:149) and Kalu (2005:226-227), missionary Christianity was generally not able to give clear guidelines on many of the issues Africans were faced with because there is nothing in Western culture and/or experience that they could refer to. This, therefore, made them treat the African worldview of the "human-spirit" continual relationship as superstition. Their attitude was explained as partly influenced by the Enlightenment culture - which says, "things which could not be scientifically and rationally proved should not be taken seriously" (Asamoah-Gyadu 2013:2).

In addressing the issue on the traditional worldview of African people, Paris (1995:37) made reference to Genovese's statement: "When Africans took over the Christian God, they simultaneously extended, rather than transcended their own practice". That is to say that African conversion to Christianity did not mean a 
wholesale exchange of their indigenous religion for a new one (Paris 1995:36). Most Ghanaian Christians still believe in the existence of ghost, witches, evil spirits, idols, etc., and are of the view that these spirits can cause havoc, misery, diseases, death, poverty and so on in one's life (Sarpong 2002:94-103). Because of this embedded worldview, Ghanaian Christians still have the fear that these invisible spirits can have a negative influence on one's life, in spite of the fact that the person has become a Christian (Ekem 2009:39). To this end, Taylor (2001:7) states that members of the mainline churches were not totally submissive to Western theological worldviews. Even though the missionaries attempted to contextualize or "indigenize" their Western Christianity, the outcomes were often "too superficial".

\section{PENTECOSTALISM IN GHANA: AFRICA INITIATED CHURCHES}

Pentecostalism emerged in Ghana due to the unaddressed concerns of the Ghanaian Christian faith community by the Western missionaries. In their pursuit of solutions for their fears, they were led by their craving for a "higher spirituality", which in turn led them to the development of prayer and bible study groups in the mainline churches, of which some separated from the mainline churches and became independent churches which emphasized the operation of the Holy Spirit (both in the church and in the lives of believers).

This separation, and the need for a "higher spirituality", led to the establishment of the African Instituted Churches, also known as "African Indigenous Churches", "African Independent Churches", or "African Initiatives in Christianity" (depending on the person using the term). According to Turner (1967:1), they are churches which have been founded in Africa by Africans, primarily for Africans. They are churches that were not started or founded by Western missionaries (Oduro et al. 2008:6).

Though the term "African Initiated Churches" represents a wider spectrum in various contexts (Kalu 2005:309), this paper's focus is on the "Spirit-type Churches" or "Spiritual Churches" (Daneel 1987:39). The focus is on the "Spirit type" because; they are the most prominent type in Ghana, where they are popularly called "Susum Sore" (Akan), "Mumu Solemo" (Ga), and "Bobome Tsotsi" (Ewe), which literally means "Spiritual Churches". They are called "Spiritual Churches" because they claim that their activities and style of worship demonstrate that every single aspect of their worship and ministry activity is being enabled through the help of the Holy Spirit (Baeta 1962:1, Larbi 2001:69).

Scholars such as Kwesi Dickson (1984), John Pobee (1991:10-12), Kwame Bediako (1995), and Asare Opoku $(1978,1980)$ are of the view that the AIC's came into being 
as a protest against the Eurocentric disposition of the mainline churches in Africa (and for that matter, Ghana). At the 2002 Inter-Theological Dialogue between representatives of a group of AIC's and that of the Mission Initiated Churches - held at Nairobi Kenya - the AIC's were described as "any African founded church which believes in Jesus Christ as Saviour, the Holy Trinity (God the Father, God the Son, and God the Holy Spirit as One God), and also believes in the Christian doctrine as presented in the Holy Bible (both the Old Testament and New Testament)" (Reformed World 2005:39).

According to Oduro et al. (2008:19), "there is an African way of understanding God and the movement of the Holy Spirit. In the same way, there is an African way of understanding the world, the visible world around us - the cattle, trees, people and cities - as well as the unseen world - the supernatural world of spirits and powers. The AIC's therefore came as a means of presenting Christianity in the African context, making Christianity relevant to Africans and their worldview". Kgatla (2013) argues that AIC's came as a response to the intolerance and ignorance of the Western Missionaries toward Africans, their worldview and culture.

Pobee and Ositelu II (1998:5) state that the AIC's represent a central development of Christianity in the Africa of the $20^{\text {th }}$ Century. This indicates that there is no way one can discuss world Christianity without talking about the AIC's. According to Bediako (1995: 66), the AIC's have pointed to the direction in which broad sections of African Christianity are moving and therefore have testified to the existence of some generalised trends in the African response to the Christian faith. In effect, the presence of both the Classical and Neo-Pentecostal Churches in Ghana was as a result of the initiative of the AIC's.

\section{CLASSICAL PENTECOSTALISM IN GHANA}

As time passed, and with the emergence of the classical Pentecostal and NeoPentecostal churches in Ghana, the AIC's began to lose popularity and members (Asamoah-Gyadu 2005:29-30). The reason was that, while the classical Pentecostal and Neo-Pentecostal churches adopted some of the traditional African styles of worship - such as drumming, clapping of hands, dancing, divine healing, and exorcism (that are practiced by the AIC's) - they criticized practices such as types of sacrifices and offering, and the use of items such as holy water, candles, and ritualistic prayers which are inconsistent with the New Testament. The Pentecostals emphasized salvation through Christ, the indwelling or the infilling of the Holy Spirit in every Christian, the gifts of the Holy Spirit, and missions through the sharing of the gospel, followed by miracles, signs, and wonders (Omenyo 2006:5). This, therefore, made the Classical and Neo-Pentecostal Churches attract many of the previous members 
of AIC's, which were more or less a syncretism between Christianity and African traditional religious practices. In Oduro's (2006:1) view, Pentecostal Charismatic Christianity is an expression of a refined African Pentecostal Christianity.

After a critical analysis of the Pentecostal Movement, Harvey Cox (1995:4-5) concludes that;

The first Pentecost event in Acts 2, serves as inspiration for people who are discontented with the way religion or the world in general is going. In order to find solutions to their challenges, they turn to Pentecostalism because it is packed with promise... it is about the experience of God not about abstract religious ideas, and it presents a God who is ever ready and caring to attend to human needs through the power of Holy Spirit.

Omenyo's (2006:244-258) historical study of Pentecostalism in the mainline churches in Ghana argues that, although Seymour never stepped on Ghanaian soil and none of his missionaries to Africa set foot in Ghana, one can trace the impact of Seymour and the Azusa Street Revival on Ghanaian Christianity through various connections. They are: the Prophet William Wade Harris connection; Apostle Peter Anim's connection with the Apostolic Faith Church (Peter Anim and his Faith Tabernacle Church are credited with the origins of Classical Pentecostalism in Ghana); The Assemblies of God Church's connection through Rev. Lloyd and Margaret Shirer, who were the first Pentecostal missionaries to Ghana in 1931; James McKeon of the Apostolic Church, the UK's connection with Anim's Asamankesebased group in 1937, and his subsequent role in the establishment of Church of Pentecost which is now the second largest church in Ghana (Larbi 2001:32-33); and, finally, the Four Square Gospel Church's connection which took place in the 1980's These encounters changed the face of Christianity in Ghana, after several years of the failure of the mainline mission organizations to attend to the spiritual needs of their members (Omenyo 2006:101-219). However, in spite of the limitations of the Western missionary-led mainline churches, the current mainline churches have also been influenced by the Pentecostal waive (Atiemo 1993).

Though many Ghanaian Pentecostal Churches claim to be doing very well in Ghana (Larbi 2001:xii), there are, however, some challenges for some of them. Until recently, many of the Ghanaian Pentecostal leaders and Pastors had little or no formal education. Where the Neo-Pentecostals are concerned, apart from the issue of education, many of them have no formal leadership succession and/ or administrative structures in their churches. Many of them also do not have structured church services and programmes. This means that the leader decides everything on his own with little or no consultation with other Pastors and/or 
leaders of the Church. What they mostly use as a cover-up is the statement: "I am led by the Holy Spirit to do A, B, and C" (and then no one can say anything). Some of the Pastors are also arrogant, especially the ones from the Neo-Pentecostal and Independent Pentecostal Churches, using their position to extort money from their congregations in order to enrich themselves.

\section{THE HOLY SPIRIT, PENTECOSTALISM AND MISSION}

While African churches typically belong to one of three types - i.e. mainline churches (stemming from Western missionaries), Pentecostal churches, and AIC's (Africa Instituted/Initiated Churches) - all of them still share the African primal religion/worldview as their spiritual bedrock. Although there were some extremely puritanical approaches to African traditions among these churches, most of them were characterized by strong pneumatology and supernatural awareness, which can be ascribed to the traditional or primal religiosity that forms the foundation of African cultural knowledge and life. This explains why charismatic Pentecostal currents have been notably detected across all three ecclesiastical types (Chul-Soo Kim 2013:123). Pentecostalism, with its African characteristics, has made a great impact on Ghanaian Christianity.

Russell (1988:133-134) asserts that Pentecostalism has emerged as the dominant Protestant spirituality. Pentecostals stress the fact that God's gifts can be experienced in the church today. Essentially, they "stress the power and presence of the Holy Spirit and the gifts of the Spirit directed towards the proclamation that Jesus Christ is Lord to the glory of God" (Vinson 1986:32).

Balia \& Kim (2010:24), in a summary of the Edinburg 2010 research, note that the last century has seen an extraordinary rise in Pentecostalism, with its Christocentric orientation and its Spirit practice, and an engagement with primal religions and a desire to inculturate Christianity by including the realm of the spirits. These experiences have influenced missiology, encouraging reflection upon the inseparable relationship between Christ and the Holy Spirit. This approach suggests that there is no part in Jesus that is not touched by the Holy Spirit. This in effect, forces one to approach missions from a Pneumatological perspective - as initiated by Jesus Christ in Luke 4:18, and also encouraged in Acts 1:8.

A Pneumatological mission approach is characteristic of the Pentecostal Churches and movements in Ghana. According to them, it takes the role of the Holy Spirit to convict sinners of their sins and to bring them into the body of Christ, a process known as "the baptism of the Holy Spirit" (Jn 16:8, Eph 2:18-21, 1 Cor 12:13,). It is also the Holy Spirit that empowers the believer to live a godly life, endowed with 
the manifestations of the gifts of the Spirit for the purpose of mission and church growth; which is also known as the infilling of the Holy Spirit (Ac 1:8; 2:1-4, Eph 4:10-14 (Asamoah-Gyadu 2013:10-11).

Connecting the role of the Holy Spirit in mission to the Trinitarian mission - what others call the missio Dei - is a point of departure clearly presented by Jesus Christ in John 20: 21-22: "'Peace be with you! As the Father has sent me, I am sending you.' And with that he breathed on them and said: 'Receive the Holy Spirit". This, therefore, means that the Father is the Sender and the Lord of the harvest; the incarnate Son is the model embodiment of the mission in the world; and the Holy Spirit is the divine empowering presence for the entire mission (Tennent 2010:75). In his book Missio Dei, Vicedom (cited by Verkuyl 1988:3) puts it this way: "God the Father sent the Son, and the Son is both the Sent One and the Sender. Together with the Father the Son sends the Holy Spirit, who in turn sends the church to participate in the mission of God in the world".

Bevans and Schroeder (2004:286-295) present the missio Dei as part of the theology of the Second Vatican Council, which traces its roots to the idea of "Divine Missions" originally developed by Augustine and the scholastic theologians of the thirteenth century, but was also influenced by the Protestant mission theology of the twentieth century, and, more recently, by Evangelical and Pentecostal theologians.

Flett (2010:9) states that, without the missio Dei, the mission of the church would simply be grasping at mere straws; it would be salvation by works alone. Mission is more than mere human activity, it belongs to God. Furthermore, "the missio Dei is not something from which the Christian community can depart. Any other conception of the ground motive and goal of mission apart from the missio Dei's Trinitarian location risks investing authority in historical accident and human capacity" Flett (2010:9). The missio Dei, affirming that mission is God's sending forth, expanded during the ecumenical discussions in the 20th century to include the participation of the church in the divine mission (Balia \& Kim 2010:23). In the missio Dei, "the Holy Spirit has a wholly unique personhood, not only in the form in which it is experienced, but also in his relationship to the Father and the Son" (Moltmann 1992:12); and "the Spirit of God is constantly at work in ways that surpass human understanding and in places that, to us, are least expected" (World Council of Churches 1992:43).

In line with the views shared above, Ghanaian Pentecostals affirm their belief in the Triune God in the following statement: "We believe in the existence of the One True God, Elohim, maker of the whole universe; indefinable, but revealed as Triune God, Father, Son and the Holy Spirit - One in nature, essence and attributes, Omnipotent, 
and Omnipresent (Gn 1:1; Mt 3:16-17; 1 Jn 5:7)" (Church of Pentecost, Ghana Tenets Article 2; Larbi 2001:280-281). This view about the Triune God has also influenced their approach to mission and also appears in their songs. In their meetings, they sing songs like:

\begin{tabular}{|c|c|}
\hline Akan language - Twi & Translation \\
\hline Ye wo nyame basan Koro & We have a three in One God (Triune God) \\
\hline Ono nkoaa na ye be som no $(2 x)$ & He is the only One we will worship \\
\hline Ye wo nyame Agya & We have God the Father \\
\hline Ye wo nyame $\underline{O b a}$ & We have God the Son \\
\hline Ye wo nyame Susumkronkron & We have God the Holy Spirit \\
\hline Ono nkoaa na yẹbe som no & He is the only One we will worship \\
\hline
\end{tabular}

In the Edinburgh 2010 Common Call, the church is described as a sign and symbol of the reign of God, called "to witness to Christ today by sharing in God's mission of love through the transforming power of the Holy Spirit" (Balia \& Kim 2010:1). One can say that, in comparing Ghanaian Pentecostal churches to the Edinburg 2010 Common Call, similarities exist: Ghanaian Pentecostal Churches see the church as people of God who are called, gathered, equipped by the Spirit, and sent to participate in God's mission by bringing the gospel of God's love and new life (Niemandt 2012:1). In comparison to the missio Dei understanding of older Catholic and Protestant missions and the "obedience to the Great Commission" of evangelical missions, Pentecostal mission is grounded first and foremost in the conviction that the Spirit is the motivating power behind this activity (Allan 2004: 206-207). Dempster (1999:48-49) asserts "the theological reflection of early Pentecostals on church mission started with the conviction that the New Testament church was called into existence and empowered for evangelistic witness throughout the world by the coming of the Holy Spirit on the day of Pentecost".

\section{CONCLUSION}

Pentecostalism became a part of Ghanaian mission and church history as a result of indigenous Ghanaian Christians in Western missionary-established churches' desire to address their "traditional spiritual concerns", which they thought/felt the Western missionaries could not address. This desire led to the emergence of Pentecostal churches in Ghana, starting with the AIC's, and later welcoming the Classical and Neo-Pentecostal churches. "Culture blended with the Holy Spirit movement" 
characterizes many Ghana Pentecostal Churches. This, therefore, made many Ghanaians comfortable to relate to them. In view of this impact, Pentecostalism is not only the predominant Christian type of worship in Ghana, but almost all the mainline churches have been "pentecostalized" as well. Apart from the role of culture in the Pentecostal churches in Ghana, they also stress the power and presence of the Holy Spirit as well as the manifestations of the gifts of the Spirit in the lives of believers for ministry in church and in mission.

\section{BIBLIOGRAPHY}

Allan, Anderson. 2004. An Introduction to Pentecostalism. Cambridge: Cambridge University Press.

Asamoah - Gyadu, John K. 2013. Contemporary Pentecostal Christianity: Interpretation from an African Context. Eugene, OR: Regnum Books International.

--- 2013. "The promise is for you and your children: Pentecostal Spirituality, Mission and Discipleship in Africa", In Wonsuk, Ma, \& Kenneth, Ross, R., (eds), Regnum Edinburgh C Centenary Series, Vol. 14. Oxford: Regnum Books International. pp. 10-12.

--- 2005. African Charismatics: Current Development within independent Indigenous Pentecostalism in Ghana. Leiden, Netherlands: Brill.

Baeta, Christian G. 1962. Prophetism in Ghana: A study of some 'spiritual church. London: SCM Press. Also in Emmanuel K. Larbi, Pentecostalism: the Eddies of Ghanaian Christianity, (2001), p. 69.

Bamfo, Atiemo. 1993. The rise of Charismatic movement in the mainline churches in Ghana. Accra: Asempa Publishers.

Bediako, Kwame. 1995. Christianity in Africa: The renewal of a Non- Western Religion Maryknoll, $\quad$ NY: Orbis Books.

Bevans, Stephen B., \& Schroeder, R.P. 2004. Constants in context: A theology of mission for today. New York: Orbis Books International.

Busia, Kofi Abrefa. 1963. "Has Faith been adequately represented?” International Review of Mission, Vol.50: pp. 86 - 89. 
--- 1972. "The commitment of the Laity in the Growth of the Church and the Integral Development of Africa", Laity today .pp. 239 - 246.

--- 2005. "Christianity in African Context", Reformed World, Vol. 55: Issue 1. p. 39.

Chul-Soo Kim, Caleb. 2013. A Missiological Review of African Christianity since Independence and Her Missional Tasks. p. 123. Retrieved from: http://cfile26. uf.tistory.com/original/237CB434513811C716C311 [2013, 17 April]

Church of Pentecost, Ghana, The Ten Tenets of the Church of Pentecost. Retrieved

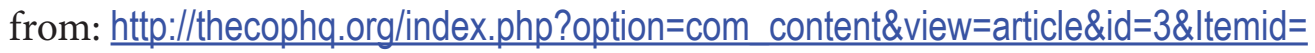
$\underline{8}[2013,12$ August $]$

Cilliers, Johan, Formations and movements of Christian spirituality in Urban African contexts. p.10. Retrieved from: http://academic.sun.ac.za/tsv/Profiles/ Profile documents/Johan Cilliers AFRICAN SPIRITUALITY.pdf [2013, 20 April]

Daneel, Inus. 1987. Quest for Belonging. Gweru, Zimbabwe: Mambo Press.

Darkwa, Amanor Jones, "Pentecostalism in Ghana: An African Reformation”, Cyber journal for Pentecostal-Charismatic Research Retrieved from: http://www. pctii.org/cyberj/cyberj13/amanor.html [2013, 21March]

Daryl, Balia \& Kirsteen, Kim. 2010. Witnessing to Christ Today, Edinburgh 2010, Volume II. Oxford: UK, Regnum Books International.

Dempster, Murray. 1999. "A Theology of the Kingdom: A Pentecostal Contribution", in Samuel \& Sugden (eds.), Mission As Transformation. Oxford: Regnum.

Dickson, Kwesi A. 1984. Theology in Africa. New York: Orbis books.

Ekem, Kwabena, John D. 2009. Priesthood in Context: A case study of Priesthood in some Christian Community and Primal Communities of Ghana and Its Relevance for Mother- Tongue Biblical interpretation. Ghana: Sonlife Press.

Flett, John G. 2010.The Witness of God: The Trinity, Missio Dei, Karl Barth and the nature of Christian community, Kindle edn. Eerdmans, Grand Rapids.

Ghana Statistical Service. 2012. Population \& Housing Census 2010. Accra, Ghana: Sakofa Press Limited. 
Harvey, Cox. 1995. Fire from Heaven: The rise of Pentecostal spirituality and reshaping of religion in the twenty-first century. Reading, MA: Addison-Wesley.

Kalu, Ogbu U., (ed.) 2005, African Christianity: An African story. University of Pretoria, Pretoria.

Kgatla, Thias, Interviewed in his office, Faculty of Theology, Department of Science of Religion and Missiology, University of Pretoria, South Africa on $3^{\text {rd }}$ August, 2013.

Kraft, Charles H. 1996. Anthropology for Christian Witness. Marykoll, N.Y: Orbis Books International.

Larbi, Emmanuel K. 2010. Pentecostalism: the Eddies of Ghanaian Christianity. Accra-Ghana, Blessed Publications.

--- 2002. "The Nature of Continuity and Discontinuity of Ghanaian Pentecostal Concept of Salvation in African Cosmology", in Asian Journal of Pentecostal Studies Vol. 5 Issue 1. p. 99. See also Ghana Evangelism Committee. 1993. National Church Survey: Facing the Unfinished Task of the Church in Ghana. Accra: Ghana Evangelism Committee. pp.16-17.

Max, Warren.1967. Social History and Christian Mission. London, S.C.M. Press, 1967.

Mbiti, John .S. 2012. Concepts of God in Africa, $2^{\text {nd }}$ Edition. Nairobi, Kenya: Acton Publishers.

Moltmann, Jürgen. 1992. Spirit of Life: A Universal Affirmation. Minneapolis: Fortress Press.

Niemandt, Cornelius J.P. 2012, "Trends in missional ecclesiology", HTS Teologiese Studies/Theological Studies 68(1), Art. \#1198, 9 pages. http://dx.doi.org/10.4102/

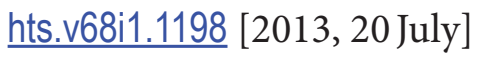

Oduro, Thomas. 2006. Journal of African Instituted Church Theology, (Good News Theological College and Seminary, Ghana), Volume II, 1:1.

Oduro, Thomas, Hennie, Pretorius, Stan, Nussbaum, \& Brain, Born. 2008. Mission in an African way: A practical introduction to African Instituted Churches and their sense of mission. Wellington, South Africa: Christian Literature Fund and Bible Media. 
Omenyo, Cephas .N. 2006. "William Seymour and African Pentecostal historiography: the case of Ghana", in Asian Journal of Pentecostal Studies, 9:2. pp. 244-258.

--- 2006. Pentecost outside Pentecostalism. Netherlands: Boekencentrum Publishing House.

Opoku, Asare. 1978. West Africa Traditional Religion. Singapore: F.E.P. International.

--- 1980. "Changes within Christianity: The case study of the Musama Disco Christo Church"; in The history of Christianity in West Africa. London: Longmans.

Paris, Peter J. 1995. The spirituality of African Peoples: The search for a Common Moral Discourse. Minneapolis: Fortress Press.

Pobee, John S. 1991. African Instituted (Independent) Churches, in N. Lossky et al (eds.), Dictionary of the Ecumenical Movement. Geneva: W.C.C Publications.

John .S. Pobee \& G. Ositelu II. 1998. African Initiatives in Christianity. Geneva: W.C.C Publications.

Rusbult, Craig, Worldview, http://www.asa3.org/ASA/education/views/index.html [2013, 20 April]

Russell, P. Spittler. 1988. “The Pentecostal View”, in Donald L. Alexander (ed.) Christian Spirituality: Five View of Sanctification. Downers Grove: Inter Varsity Press. pp. 133-134.

Sarpong, Peter Kwesi. 2002. People Differ: An approach to inculturation in Evangelism. Accra: Sub-Sahara Publishers.

Taylor, John V. 2001. Christian Presence amid African Religion. Nairobi: Acton Publishers.

Tennent, Timothy C. 2010. Invitation to World Mission: A Trinitarian missiology for the Twenty-first Century. Grand Rapids, M.I: Kregel Publications.

Turner, Harold W. 1967. "A typology of African Religious Movements", Journal for African Religion, 1: p.1. 
Van den Toren, Brenno. 2013. "Teaching ethics in the face of African moral crisis: Reflection from a guest" in Transformation: An international Journal of Holistic Mission Studies, Vol. 30, No 1. pp. 7-8.

Verkuyl, Johannes. 1988. Contemporary Missiology. Grand Rapids, Michigan: Eerdmans Publishing Co.

Vinson, Synan. 1986. 'Pentecostalism: Varieties and contributions', Pneuma, Vol. 8. pp.32.

Walls, Andrew F. 1996. "African Christianity in the History of Religion", Studies in World Christianity 2:2. p.194.

Williamson, Sidney G. 1965. Akan Religion and the Christian Faith (ed.,) Kwesi Dickson. Accra: Ghana University Press.

World Council of Churches. 1992. "Ecumenical Affirmation: Mission and Evangelism," in Scherer, James A., \& Stephen B. Bevans, eds. New Directions in Mission and Evangelization: Theological Foundations. Maryknoll, NY: Orbis Books International.

\section{KEY WORDS}

Missiology

Pentecostalism

Mission

Holy Spirit

Ghana

African Initiated Churches

Worldview

\section{TREFWOORDE}

Missiologie

Pentekostalisme

Sending

Heilige Gees

Ghana

Afrika Onafhanklike Kerke

Wêreldbeskouing 


\section{CONTACT DETAILS}

White, Peter

Science of Religion and Missiology

University of Pretoria

South Africa

pastorwhite@hotmail.com

Tel: +27 604329511

Niemandt, Cornelius, JP

Head of Department, Science of Religion and Missiology

University of Pretoria

South Africa

nelus@pixie.co.za

Tel: +27 824511670 
